\title{
Circadian methane oxidation in the root zone of rice plants
}

\section{Journal Article}

\section{Author(s):}

Cho, R.; Schroth, Martin Herbert (D; Zeyer, J.

Publication date:

2012-11

Permanent link:

https://doi.org/10.3929/ethz-b-000043343

Rights / license:

In Copyright - Non-Commercial Use Permitted

Originally published in:

Biogeochemistry 111(1-3), https://doi.org/10.1007/s10533-011-9651-6 


\title{
Circadian methane oxidation in the root zone of rice plants
}

\author{
R. Cho $\cdot$ M. H. Schroth $\cdot$ J. Zeyer
}

Received: 21 February 2011 / Accepted: 3 September 2011/Published online: 16 September 2011

(C) Springer Science+Business Media B.V. 2011

\begin{abstract}
In the root zone of rice plants aerobic methanotrophic bacteria catalyze the oxidation of $\mathrm{CH}_{4}$ to $\mathrm{CO}_{2}$, thereby reducing $\mathrm{CH}_{4}$ emissions from paddy soils to the atmosphere. However, methods for in situ quantification of microbial processes in paddy soils are scarce. Here we adapted the push-pull tracer-test (PPT) method to quantify $\mathrm{CH}_{4}$ oxidation in the root zone of potted rice plants. During a PPT, a test solution containing $\mathrm{CH}_{4} \pm \mathrm{O}_{2}$ as reactant(s), $\mathrm{Cl}^{-}$and $\mathrm{Ar}$ as nonreactive tracers, and BES as an inhibitor of $\mathrm{CH}_{4}$ production was injected into the root zone at different times throughout the circadian cycle (daytime, early nighttime, late nighttime). After a 2-h incubation phase, the test solution/pore-water mixture was extracted from the same location and rates of $\mathrm{CH}_{4}$ oxidation were calculated from the ratio of measured reactant and nonreactive tracer concentrations. In separate rice pots, $\mathrm{O}_{2}$ concentrations in the vicinity of rice roots were measured throughout the circadian cycle using a fiberoptic sensor. Results indicated highly variable $\mathrm{CH}_{4}$ oxidation rates following a circadian pattern. Mean rates at daytime and early nighttime varied from 62 up to $451 \mu \mathrm{mol} \mathrm{l}{ }^{-1} \mathrm{~h}^{-1}$, whereas at late nighttime $\mathrm{CH}_{4}$ oxidation rates were low, ranging from 13 to $37 \mu \mathrm{mol}$ $\mathrm{l}^{-1} \mathrm{~h}^{-1}$. Similarly, daytime $\mathrm{O}_{2}$ concentration in the
\end{abstract}

R. Cho · M. H. Schroth $(\bowtie) \cdot J$. Zeyer

Institute of Biogeochemistry and Pollutant Dynamics,

ETH Zurich, Universitätstrasse 16, 8092 Zurich,

Switzerland

e-mail: martin.schroth@env.ethz.ch vicinity of rice roots increased to up to $250 \%$ air saturation, while nighttime $\mathrm{O}_{2}$ concentration dropped to below detection $(<0.15 \%$ air saturation). Our results suggest a functional link between root-zone $\mathrm{CH}_{4}$ oxidation and photosynthetic $\mathrm{O}_{2}$ supply.

Keywords Circadian variation · In situ quantification - Methane oxidation - Oxygen · Push-pull test · Paddy soil

\section{Introduction}

Methane $\left(\mathrm{CH}_{4}\right)$ is an important greenhouse gas with a warming potential per molecule $\sim 25$ times higher than that of carbon dioxide for a calculation period of 100 years (Forster et al. 2007). Among other natural and anthropogenic sources, rice (paddy) soils emit an estimated 31-112 $\mathrm{Tg} \mathrm{CH}_{4} \mathrm{a}^{-1}$, thus contributing about 6-18\% to global $\mathrm{CH}_{4}$ emissions (Denman et al. 2007). The uncertainty in emission estimates is partially due to a limited understanding of the factors controlling $\mathrm{CH}_{4}$ turnover in paddy soils. Thus, better knowledge on the controls of $\mathrm{CH}_{4}$ dynamics in paddy soils is needed to improve $\mathrm{CH}_{4}$ emission predictions and to develop more effective mitigation and management strategies (van Bodegom et al. 2001; Wassmann et al. 1993; Yagi et al. 1997).

In paddy soils, $\mathrm{CH}_{4}$ is produced by methanogenic archaea when soils turn anoxic after flooding (e.g., Kumaraswamy et al. 2000). Generated $\mathrm{CH}_{4}$ may be 
released to the atmosphere by (1) diffusional transport through the rice plants' aerenchyma, (2) aqueous diffusion to the water table and subsequent partitioning across the air/water interface, and (3) gas-bubble ebullition. Among the three pathways, plant-diffusional transport was found to be dominant in paddy soils (Holzapfel-Pschorn and Seiler 1986; Nouchi et al. 1990; Schütz et al. 1989; Seiler et al. 1983; van der Gon and van Breemen 1993).

However, a substantial fraction of produced $\mathrm{CH}_{4}$ may never reach the atmosphere due to the activity of aerobic methanotrophic bacteria (e.g., Liesack et al. 2000). These organisms catalyze the oxidation of $\mathrm{CH}_{4}$ to $\mathrm{CO}_{2}$, with $\mathrm{CH}_{4}$ serving as carbon and energy source, and $\mathrm{O}_{2}$ being the terminal electron acceptor (Hanson and Hanson 1996). Whereas aerobic methanotrophic bacteria are ubiquitous in paddy soils (Gilbert and Frenzel 1998), aerobic $\mathrm{CH}_{4}$ oxidation occurs only at oxic/anoxic interfaces, where both $\mathrm{O}_{2}$ and $\mathrm{CH}_{4}$ are present. Therefore, aerobic methanotrophs are most abundant and active at locations such as the soil/water interface and near the root surface in the rice plants' root zone (Bosse and Frenzel 1997; Eller et al. 2005). At the soil/water interface, approximately $80 \%$ of the diffusive $\mathrm{CH}_{4}$ flux (gas-bubble ebullition not included) is oxidized to $\mathrm{CO}_{2}$ (Conrad and Rothfuss 1991; Epp and Chanton 1993; Gilbert and Frenzel 1995). In contrast, balance studies revealed that estimates for $\mathrm{CH}_{4}$ oxidation in the root zone vary from 0 to $94 \%$ of the potential $\mathrm{CH}_{4}$ flux through the plants' aerenchyma (Chanton et al. 1997), depending on method applied and plant-growth stage. Large variations in the efficiency of root-zone $\mathrm{CH}_{4}$ oxidation may also be attributed to various factors that are discussed controversially in the literature. Several studies concluded that $\mathrm{CH}_{4}$ concentration is the ratelimiting factor (Gilbert and Frenzel 1995; van der Gon and Neue 1996). In contrast, availability and competition for $\mathrm{O}_{2}$ as a control of $\mathrm{CH}_{4}$ oxidation was proposed by others (King 1996; van Bodegom et al. 2001). Oxygen is delivered to the root zone of rice plants and other aquatic macrophytes by diffusional transport through the plants' aerenchyma and subsequent $\mathrm{O}_{2}$ leakage from the roots (Armstrong 1964; Calhoun and King 1997; Oremland and Taylor 1977). Reported concentrations of $\mathrm{O}_{2}$ near roots vary dependent on age, species and in which zone measured (Christensen et al. 1994; Frenzel et al. 1992). Furthermore, it was reported that the magnitude of radial $\mathrm{O}_{2}$ loss from roots of completely submerged rice seedlings was correlated with light (Colmer and Pedersen 2008; Waters et al. 1989).

Different approaches have been employed to measure root-zone $\mathrm{CH}_{4}$ oxidation, e.g. mass balances between $\mathrm{CH}_{4}$ production in soil incubations and emission-flux measurements from plants (Bosse and Frenzel 1997; Henckel et al. 2000; Schütz et al. 1989), or $\mathrm{CH}_{4}$ emission fluxes under inhibited and undisturbed conditions (Epp and Chanton 1993; Krüger et al. 2001). However, the efficiency of inhibitors such as methyl fluoride or difluoromethane, when applied to the headspace of chamber enclosures, strongly depends on the effectiveness of diffusional transport in plants. Similarly, plant incubations under $\mathrm{N}_{2}$ atmosphere to determine $\mathrm{CH}_{4}$ emission flux in the absence of $\mathrm{CH}_{4}$ oxidation may artificially enhance $\mathrm{CH}_{4}$ production, and thus lead to overestimation of $\mathrm{CH}_{4}$ oxidation activity when compared to flux measurements in the presence of $\mathrm{O}_{2}$ (Holzapfel-Pschorn et al. 1985; van der Gon and Neue 1996). Finally, stable isotope measurements $\left({ }^{13} \mathrm{C} /{ }^{12} \mathrm{C}\right.$ ratios and ${ }^{13} \mathrm{C}$ labeling) were used in several studies to assess $\mathrm{CH}_{4}$ oxidation in the root zone (Gerard and Chanton 1993; Groot et al. 2003; Krüger et al. 2002). As microbial $\mathrm{CH}_{4}$ oxidation causes isotope fractionation in the signature of $\mathrm{CH}_{4}$, differences in ${ }^{13} \mathrm{C} /{ }^{12} \mathrm{C}$ ratios between root-zone $\mathrm{CH}_{4}$ and $\mathrm{CH}_{4}$ emitted through rice plants may be used to assess and quantify $\mathrm{CH}_{4}$ oxidation. However, this approach needs to be used with caution, as additional fractionation due to diffusional transport through the root-shoot transition zone as well as variations in fractionation factors may occur (Butterbach-Bahl et al. 1997; Rao et al. 2008).

Another method for in situ quantification of microbial processes in subsurface environments is the single-well injection-withdrawal test, hereafter referred to as a "push-pull test" (PPT) (Istok et al. 1997). The method consists of injection of an aqueous test solution containing reactant(s) and nonreactive tracer(s) (hereafter referred to as tracer) through a single well at a point of interest, followed by extraction of the test solution/pore water mixture from the same location. An incubation phase after injection may be included to allow for additional reactant turnover. Rate constants may be computed from concentration ratios of reactants (or metabolic products formed) and nonreactive tracers, as measured in samples collected during the PPT's extraction phase 
(Haggerty et al. 1998; Schroth and Istok 2006). Pushpull tests were successfully applied in contaminated aquifers to quantify a variety of microbial processes including aerobic respiration, denitrification, sulfate reduction and $\mathrm{CH}_{4}$ production (e.g., Istok et al. 1997; Kleikemper et al. 2002), as well as reductive dehalogenation (Hageman et al. 2004) and aerobic cometabolism of chlorinated compounds (Kim et al. 2006). In addition, the method was adapted for use in the gaseous phase ("gas push-pull test") to quantify aerobic $\mathrm{CH}_{4}$ oxidation in the soil vadose zone (e.g., Gomez et al. 2009; Urmann et al. 2005). While the majority of studies interrogated relatively large subsurface volumes by injecting tens to hundreds of liters of test solution, several recent studies demonstrated the utility of PPTs to quantify microbial processes at smaller scales using injection volumes between 10 and $200 \mathrm{ml}$ (Bassein and Jaffe 2009; Koop-Jakobsen and Giblin 2009; Sanders and Trimmer 2006).

The main objective of this study was to adapt PPTs to allow quantification of $\mathrm{CH}_{4}$ oxidation in the root zone of rice plants under defined conditions in a greenhouse. In particular, we wanted to assess the effect of varying (circadian) $\mathrm{O}_{2}$ supply through the plants' aerenchyma on $\mathrm{CH}_{4}$ oxidation activity. In four rice pots, $\mathrm{O}_{2}$ concentrations in the root zone of rice plants were measured using a fiber-optic device to examine circadian $\mathrm{O}_{2}$ dynamics under daytime/nighttime conditions. We performed a series of PPTs in four separate pots under different daytime/nighttime conditions and in the presence/absence of $\mathrm{O}_{2}$ in injected test solutions. Additional PPTs employing ${ }^{13} \mathrm{CH}_{4}$ were performed to support our methodological procedure, while two PPTs (with/without $\mathrm{C}_{2} \mathrm{H}_{2}$ as an inhibitor for $\mathrm{CH}_{4}$ oxidation) were performed to corroborate that apparent $\mathrm{CH}_{4}$ consumption was microbially mediated.

\section{Materials and methods}

\section{Rice cultivation}

Rice plants (Oryza sativa, wild type pp309) were cultivated in a greenhouse in 5-1 pots using a mixture of one third each (by volume) loamy agricultural soil, quartz sand (0.7-1.2 mm diam.), and dried rice straw that served as fertilizer substitute. In each pot, three rice plants were planted in a triangle. The soil mixture was packed into pots on top of a layer of perlite $(0.51)$.
To conduct experiments, rice plants were transferred to a climate chamber operated under similar conditions as the greenhouse: Plants were illuminated for $11 \mathrm{~h}$ (hereafter referred to as "daytime", light intensity was $\sim 20000$ lux just above plants) and kept in dark for $11 \mathrm{~h}$ ("nighttime"). Daytime conditions were $28^{\circ} \mathrm{C}$ and $80 \%$ rel. humidity; nighttime conditions were $20^{\circ} \mathrm{C}$ and $60 \%$ rel. humidity. Two 1 -hrtransition phases were included to mimic "dawn" and "dusk". To further distinguish nighttime experiments, we will use the term "early nighttime" to refer to experiments beginning shortly after the onset of nighttime, and "late nighttime" for experiments beginning at least $3 \mathrm{~h}$ after the onset of nighttime. At the time of the experiments, the plants were in the ripening phase (assessed by visual observation). Grains were mostly hard and yellow colored and pots were completely rooted. Rice shoots were intact and green with some leafs already decaying, which is common at this stage. During all experiments, the water table was maintained at $2-3 \mathrm{~cm}$ above the soil surface.

\section{Root-zone $\mathrm{O}_{2}$ dynamics}

Oxygen concentrations in the vicinity of rice roots were measured using a Fibox-3-Trace fiber-optic $\mathrm{O}_{2}$ meter in combination with the Trace oxygen dipping probe (Fig. 1, Presens, Regensburg, Germany). Briefly, the method is based on the excitation of dye molecules coated onto a sensor foil at the tip of a

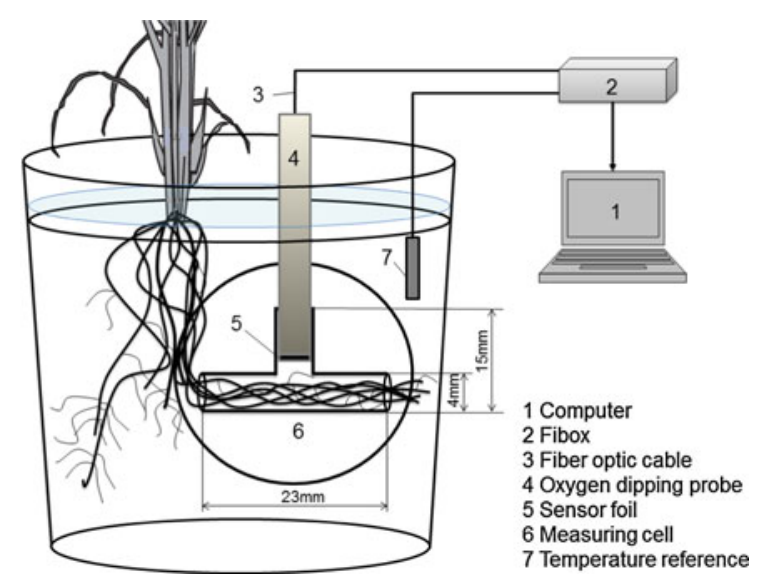

Fig. 1 Oxygen measurement principle employing the fiberoptic $\mathrm{O}_{2}$ meter. For better visualization the measuring cell is enlarged within the circle (i.e., not to scale) 
dipping probe by an LED light pulse transmitted through a fiber-optic cable. The resulting luminescence of dye molecules is recorded by the transmitter. In the presence of $\mathrm{O}_{2}$ this luminescence is quenched, with the quenching effect being proportional to the partial pressure of $\mathrm{O}_{2}$. Before measurements a twopoint calibration was performed with the software Oxy-View PST3 provided by the manufacturer including automatic temperature compensation. For probe calibration, ambient air as $100 \%$ and $\mathrm{N}_{2}$ gas (Pangas, Dagmarsellen, Switzerland; >99.999 Vol.\%) as zero value were used. The probe's detection limit was $0.15 \%$ air saturation. Note that in contrast to Clark-type electrodes, no $\mathrm{O}_{2}$ was consumed during these measurements.

To facilitate $\mathrm{O}_{2}$ measurements, a fraction of roots of individual rice plants was gently excavated from the soil and carefully rinsed with water. Depending on size, between 5 and 10 washed roots were placed into a measuring cell (L $23 \mathrm{~mm}, \mathrm{H} 15 \mathrm{~mm}$, ID $4 \mathrm{~mm}$ ) equipped with the $\mathrm{O}_{2}$ dipping probe and open on both sides (Fig. 1). Only roots that appeared white or redbrownish (partially encrusted) were used for this purpose, while blackish (fully encrusted) roots were omitted. The measuring cell was then water-saturated and buried $2-3 \mathrm{~cm}$ below the soil surface. For four different rice plants, $\mathrm{O}_{2}$ concentrations were continuously monitored for at least 2 daytime/nighttime cycles using the probe manufacturer's software.

Push-pull test design

We conducted a total of 20 PPTs in the rice-root zone of five different pots (Table 1). Apart from 14 standard PPTs, four tests were performed using ${ }^{13} \mathrm{CH}_{4}$ (R1-4 ${ }^{13} \mathrm{C}$, Table 1), while the final two tests were performed to verify that $\mathrm{CH}_{4}$ consumption during the tests was microbially mediated (R5, Table 1).

Table 1 Experimental parameters during 20 PPTs performed to quantify $\mathrm{CH}_{4}$ oxidation in the root zone of rice plants at daytime (D), early nighttime (EN) and late nighttime (LN)

\begin{tabular}{|c|c|c|c|c|c|c|c|c|}
\hline \multirow[t]{2}{*}{ PPT } & \multirow[t]{2}{*}{ Time } & \multirow[t]{2}{*}{$\mathrm{O}_{2}$} & \multicolumn{3}{|c|}{ Injection concentration } & \multicolumn{3}{|c|}{$\mathrm{BG}$ prior to PPT } \\
\hline & & & $\mathrm{Cl}^{-}(\mathrm{mM})$ & $\operatorname{Ar}(\mu \mathrm{M})$ & $\mathrm{CH}_{4}(\mu \mathrm{M})$ & $\mathrm{Cl}^{-}(\mathrm{mM})$ & $\operatorname{Ar}(\mu \mathrm{M})$ & $\mathrm{CH}_{4}(\mu \mathrm{M})$ \\
\hline R1a & $\mathrm{D}$ & + & 2.37 & 150 & 167 & 0.61 & 5 & 5 \\
\hline $\mathrm{R} 2 \mathrm{a}$ & $\mathrm{D}$ & + & 1.95 & 601 & 248 & 0.54 & 9 & 21 \\
\hline $\mathrm{R} 4 \mathrm{a}$ & $\mathrm{D}$ & + & 1.74 & 573 & 236 & 0.49 & 11 & 32 \\
\hline $\mathrm{R} 1 \mathrm{~b}$ & $\mathrm{D}$ & - & 2.42 & 640 & 306 & 0.49 & 37 & 12 \\
\hline $\mathrm{R} 2 \mathrm{~b}$ & $\mathrm{D}$ & - & 2.1 & 582 & 268 & 0.57 & 11 & 18 \\
\hline $\mathrm{R} 3 \mathrm{~b}$ & $\mathrm{D}$ & - & 2.3 & 621 & 294 & 0.43 & 35 & 12 \\
\hline $\mathrm{R} 4 \mathrm{~b}$ & $\mathrm{D}$ & - & 2.05 & 543 & 255 & 0.52 & 12 & 27 \\
\hline $\mathrm{R} 1 \mathrm{c}$ & LN & + & 2.5 & 231 & 124 & 0.78 & 7 & 4 \\
\hline $\mathrm{R} 2 \mathrm{c}$ & LN & + & 2.01 & 569 & 244 & 0.5 & 24 & 5 \\
\hline $\mathrm{R} 4 \mathrm{c}$ & LN & + & 2.02 & 559 & 241 & 0.36 & 26 & 5 \\
\hline R1d & EN & - & 2.41 & 609 & 289 & 0.39 & 29 & 23 \\
\hline $\mathrm{R} 2 \mathrm{~d}$ & EN & - & 2.49 & 609 & 277 & 0.38 & 20 & 6 \\
\hline $\mathrm{R} 3 \mathrm{~d}$ & EN & - & 2.41 & 595 & 281 & 0.31 & 28 & 15 \\
\hline $\mathrm{R} 4 \mathrm{~d}$ & LN & - & 2.53 & 632 & 292 & 0.35 & 21 & 11 \\
\hline $\mathrm{R} 1{ }^{13} \mathrm{C}$ & $\mathrm{D}$ & + & 1.66 & 270 & 221 & 0.12 & 65 & $46-61$ \\
\hline $\mathrm{R} 2{ }^{13} \mathrm{C}$ & $\mathrm{D}$ & + & 1.94 & 275 & 122 & 0.4 & 50 & $61-71$ \\
\hline R3 ${ }^{13} \mathrm{C}$ & $\mathrm{D}$ & + & 1.64 & 283 & 251 & 0.2 & 66 & 39-117 \\
\hline $\mathrm{R} 4{ }^{13} \mathrm{C}$ & $\mathrm{D}$ & + & 2.04 & 271 & 138 & 0.38 & 54 & $53-73$ \\
\hline R5 act. & $\mathrm{D}$ & + & 2.93 & 124 & 91 & 0.51 & 3 & 12 \\
\hline R5 inhib. & $\mathrm{D}$ & + & 2.55 & 77 & 69 & 0.28 & 3 & 8 \\
\hline
\end{tabular}

R1-5 represent five different rice pots, a-d represents the sequence of standard PPTs in individual pots, and " \pm " indicates if additional $\mathrm{O}_{2}$ was supplied during PPTs. Background concentrations (BG) prior to PPTs but after flushing are displayed, except for values of ${ }^{13} \mathrm{C}$ PPTs, which reflect background concentrations of the undisturbed system 
In general, to perform a PPT, a customized cylindrical stainless-steel injector (3-cm diam., 3.5$\mathrm{cm}$ long, Bopp AG, Zurich, Switzerland) consisting of a 5-layer, sintered wire mesh was installed in each pot $\sim 2 \mathrm{~cm}$ below the soil surface (Fig. 2). The injector was connected via tygon and Teflon tubing to a Nova System 16-4 piston pump (Encynova, Car-May LLC, Greeley, CO, USA). The dead volume of the system (the volume that could not be pre-flushed with test solution prior to injection) was $\sim 29$ or $36 \mathrm{ml}$. Before each PPT, samples for background concentrations of relevant species in pore water were collected in duplicate at the three-way valve closest to the injector. Thereafter, $70 \mathrm{ml}$ of a previously prepared test solution (see below) was injected at a flow rate of $\sim 10 \mathrm{ml} / \mathrm{min}$ (Fig. 2a). During injection, test-solution samples were collected in duplicate to determine relevant species' injection concentrations (Table 1). After a 2-h incubation phase, $250 \mathrm{ml}$ of the test solution/pore-water mixture was extracted at a flow rate of $\sim 10 \mathrm{ml} / \mathrm{min}$ and sampled in regular intervals (Fig. 2b). Total test duration was $\sim 2.5$ h. All samples were subdivided for ion analysis $(1 \mathrm{ml})$ and gas analysis ( $7 \mathrm{ml}$ injected into 20 - $\mathrm{ml}$ vials, which were previously sealed with butyl rubber stoppers, crimped, and flushed with $\mathrm{N}_{2}$ gas). Samples for ion analysis were kept frozen until analyzed. Samples for gas analysis were stored at $4^{\circ} \mathrm{C}$.

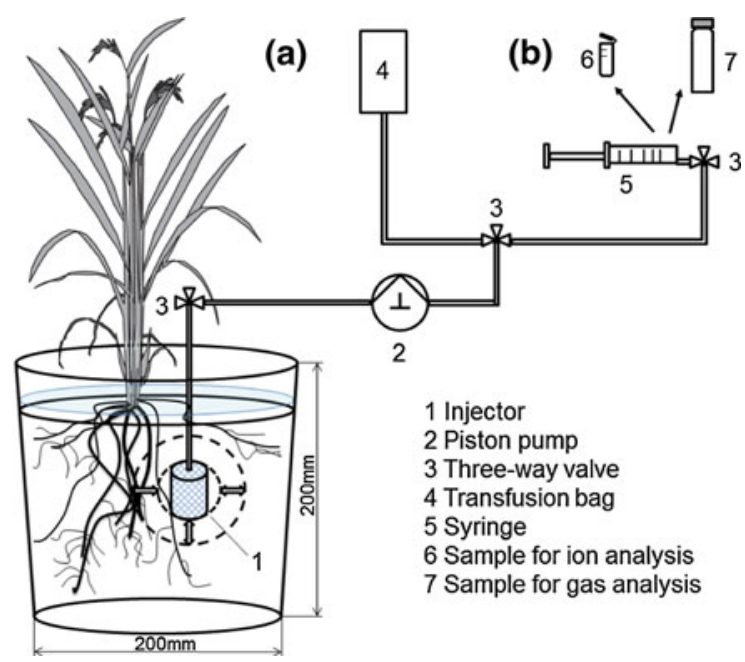

Fig. 2 Simplified scheme of the PPT procedure in the rice-root zone. a Injection phase and $\mathbf{b}$ extraction phase. Only one of three rice plants is shown for clarity
Standard PPTs to quantify $\mathrm{CH}_{4}$ oxidation

To quantify $\mathrm{CH}_{4}$ oxidation from standard PPTs, rice pots R1-R4 were flushed prior to injection of test solution with 101 of anoxic water and additionally with 11 of anoxic $10 \mathrm{mM}$ 2-bromoethane-sulfonate (BES) solution. Flushing with anoxic water was performed to reduce high and variable $\mathrm{CH}_{4}$ background concentrations in pore water (Table 1), which had caused difficulties in data analyses of preliminary PPTs (not shown). Flushing with BES was done to inhibit $\mathrm{CH}_{4}$ production; the effective concentration range of $\mathrm{BES}$ for inhibition of $\mathrm{CH}_{4}$ production was inferred from preliminary batch experiments (not shown). Test solutions for standard PPTs consisted of $2 \mathrm{mM} \mathrm{Cl}^{-}$as ionic tracer and $10 \mathrm{mM} \mathrm{BES}$ dissolved in deionized water, which was subsequently sparged for at least $35 \mathrm{~min}$ with a gas mixture consisting of $50 \mathrm{vol} . \% \mathrm{Ar}$ as dissolved-gas tracer and $30 \% \mathrm{CH}_{4} / 20 \% \mathrm{O}_{2}$ as reactants, or, $50 \% \mathrm{Ar}, 30 \% \mathrm{CH}_{4}$ and $20 \% \mathrm{~N}_{2}$ for experiments without external $\mathrm{O}_{2}$ supply (Table 1). Test solutions were subsequently transferred to transfusion bags (Macopharma, Mouvaux, France) and kept under water to minimize gas exchange.

Verification of standard PPT procedure and microbial $\mathrm{CH}_{4}$ oxidation

To assess the effect of extensive flushing of rice pots on methanotrophic activity, four PPTs utilizing ${ }^{13} \mathrm{CH}_{4}$ were performed in rice pots $\mathrm{R} 1-\mathrm{R} 4$ prior to standard PPTs (Table 1). In ${ }^{13} \mathrm{C}$ PPTs extensive flushing was unnecessary due to the low natural abundance of ${ }^{13} \mathrm{C}$ in background pore water. Instead, rice pots were only flushed with 11 of anoxic $10 \mathrm{mM}$ BES solution prior to PPTs to inhibit $\mathrm{CH}_{4}$ production. Test solutions were prepared in similar fashion as before, however, without addition of $\mathrm{CH}_{4}$ to the sparged gas mixture. Rather, $5 \mathrm{ml}$ of ${ }^{13} \mathrm{CH}_{4}$ gas (99 atom $\%{ }^{13} \mathrm{C}$, Isotec ${ }^{\mathrm{TM}}$, Miamisburg, Ohio, USA) was directly injected into transfusion bags and equilibrated with the test solutions.

Finally, two additional PPTs were performed in a separate rice pot (R5, Table 1) to verify that $\mathrm{CH}_{4}$ consumption during the tests was microbially mediated. The first PPT (R5 act.) was performed in similar fashion as described above for standard PPTs. For the second PPT (R5 inhib.), $5 \% \mathrm{C}_{2} \mathrm{H}_{2}$, an inhibitor for $\mathrm{CH}_{4}$ 
oxidation (Yoshinari and Knowles 1976), was additionally added to the sparged gas mixture.

Analytical methods

Chloride and BES were measured on a DX-320 ionchromatography system (Dionex, Sunnyvale, CA, USA) as described by Kleikemper et al. (2002). Methane and $\mathrm{C}_{2} \mathrm{H}_{2}$ were quantified using a gas chromatograph (Trace GC Ultra, Thermo Fisher Scientific, Rodano, Italy) equipped with a Porapak-N column at $85^{\circ} \mathrm{C}$ and an FID detector. Carrier gas was $\mathrm{N}_{2}$. Argon was measured on a gas chromatograph (Trace GC Ultra, Thermo Fisher Scientific, Rodano, Italy) equipped with a TCD detector and a 5AMolsieve column (10-m long, 2-mm i.d.) at $35^{\circ} \mathrm{C}$ with a back-flushed pre-column to remove $\mathrm{CO}_{2}$ and $\mathrm{H}_{2} \mathrm{O}$ (Gonzalez-Gil et al. 2007). Carrier gas was $\mathrm{N}_{2}$. Analysis of ${ }^{13} \mathrm{CH}_{4}$ (for PPTs R1-4 ${ }^{13} \mathrm{C}$ ) was performed on a Trace GC Ultra (Thermo Fisher Scientific, Rodano, Italy) equipped with a $5 \mathrm{~A}-$ Molsieve column (PLOT fused silica, 25-m long, 0.32-mm i.d., CP7536, Varian) with hydrogen as carrier gas at $30^{\circ} \mathrm{C}$ and coupled to a DSQ mass spectrometer (Thermo Fisher Scientific, Rodano, Italy). Quantification was accomplished using the Xcalibur software package (Thermo Fisher Scientific Inc., USA).

Measured gas-phase concentrations of $\mathrm{CH}_{4}$ and $\mathrm{Ar}$ were converted to aqueous-phase (dissolved) concentrations using respective Henry constants at $20^{\circ} \mathrm{C}$ (in atm/mol: $37600\left(\mathrm{CH}_{4}\right)$ and 36960 (Ar) (Sander 1999)) employing the calculation method of Kampbell and Vandegrift (1998).

\section{Estimation of kinetic parameters}

To generate breakthrough curves (BTCs) and for subsequent estimation of kinetic parameters, measured concentrations for $\mathrm{Cl}^{-}, \mathrm{CH}_{4}$ and $\mathrm{Ar}$ were converted to relative concentrations $\left(C^{*}\right)$ by dividing concentrations from extraction samples by the respective injection concentration after correction for background concentration contained in pore water. In this fashion, relative $\mathrm{Cl}^{-}$concentrations $\left(C_{\mathrm{Cl}}^{*}\right)$ were computed using (Kim et al. 2006):

$C_{\mathrm{Cl}}^{*}=\left(C_{\mathrm{Cl}}-C_{\mathrm{Cl}, \mathrm{bg}}\right) /\left(C_{\mathrm{Cl}, \mathrm{inj}}-C_{\mathrm{Cl}, \mathrm{bg}}\right)$

where $C_{\mathrm{Cl}}$ is $\mathrm{Cl}^{-}$concentration in an extraction sample, $C_{\mathrm{Cl}, \mathrm{bg}}$ is background concentration in pore water, and $C_{\mathrm{Cl}, \text { inj }}$ is injection concentration. Here, $C_{\mathrm{Cl}}^{*}$ provides a measure of dilution between injected test solution and background pore water. It was subsequently used to correct relative $\mathrm{CH}_{4}\left(C_{\mathrm{CH}_{4}}^{*}\right)$ and $\mathrm{Ar}$ $\left(C_{\mathrm{Ar}}^{*}\right)$ concentrations according to (Nauer and Schroth 2010):

$C_{\mathrm{CH}_{4}}^{*}=\left[C_{\mathrm{CH}_{4}}-\left(1-C_{\mathrm{Cl}}^{*}\right) C_{\mathrm{CH}_{4}, \mathrm{bg}}\right] / C_{\mathrm{CH}_{4}, \mathrm{inj}}$

$C_{\mathrm{Ar}}^{*}=\left[C_{\mathrm{Ar}}-\left(1-C_{\mathrm{Cl}}^{*}\right) C_{\mathrm{Ar}, \mathrm{bg}}\right] / C_{\mathrm{Ar}, \mathrm{inj}}$

where $C_{\mathrm{CH}_{4}}$ and $C_{\mathrm{Ar}}$ are $\mathrm{CH}_{4}$ and $\mathrm{Ar}$ concentrations in extraction samples, $C_{\mathrm{CH}_{4} \text {,bg }}$ and $C_{\mathrm{Ar}, \mathrm{bg}}$ are their background concentrations in pore water, and $C_{\mathrm{CH}_{4} \text {,inj }}$ and $C_{\mathrm{Ar} \text {,inj }}$ are injection concentrations. For ${ }^{13} \mathrm{CH}_{4}$, background concentration was considered negligible compared to the amount added during ${ }^{13} \mathrm{C}$ PPTs, thus no correction for these data was implemented. Breakthrough curves for different compounds were then obtained by plotting $C^{*}$ versus relative extracted volume (i.e. extracted volume $V_{\text {ext }}$ divided by total injected volume $V_{\text {inj }}$ (Istok et al. 1997)).

To determine apparent rate coefficients $k\left(\mathrm{~h}^{-1}\right)$ for $\mathrm{CH}_{4}$ oxidation, we plotted for each sample $j$ the natural logarithm of $C_{\mathrm{CH}_{4}}^{*} / C_{\mathrm{Ar}}^{*}$ against computed residence time $\left(t_{R}\right)$, thus accounting for partial consumption of $\mathrm{CH}_{4}$ during PPTs' injection and incubation phases (Schroth and Istok 2006):

$\ln \left(\frac{C_{\mathrm{CH} 4}^{*}}{C_{\mathrm{Ar}}^{*}}\right)_{j}=k t_{R, j}$

with

$t_{R, j}=t_{j}^{*}+\frac{\int_{t_{\mathrm{ext}}=0}^{t_{\text {ex } j}} Q_{\mathrm{ext}} C_{\mathrm{Cl}, \mathrm{corr}}(t) \mathrm{d} t}{M_{\mathrm{Cl}}} T_{\mathrm{inj}}$

where $t^{*}$ is time since the end of injection, $t_{\mathrm{ext}}$ is time since extraction began, $Q_{\text {ext }}$ is extraction flow rate, $C_{\mathrm{Cl} \text {,corr }}$ is background-corrected $\mathrm{Cl}^{-}$concentration, $M_{\mathrm{Cl}}$ is the total mass of $\mathrm{Cl}^{-}$injected, and $T_{\text {inj }}$ is injection time. Estimates for $k$ were obtained by fitting Eq. 4 to quasi-linear segments of experimental data using linear regression. The first five data points of each test were omitted from fitting, as they represented the system's dead volume. Note that while $\mathrm{Cl}^{-}$was used to account for dilution of test solution with background pore water during PPTs, Ar was employed for rate calculations because of its similar physical transport properties compared to $\mathrm{CH}_{4}$ (diffusion coefficients in air at $25^{\circ} \mathrm{C}$ in $\mathrm{cm}^{2} / \mathrm{s}$ : 0.19 for $\mathrm{Ar}$ 
(calculated according to Fuller et al. (1966)); 0.23 for $\mathrm{CH}_{4}$ (Massman 1998); Henry constants see above). Thus, Ar was used to account for possible dissolved $\mathrm{CH}_{4}$ losses due to partitioning into trapped gas bubbles, diffusional plant transport, and outgassing across the air/water interface. The diffusion coefficients of tracers and reactants in water (at $25^{\circ} \mathrm{C}$ in $\mathrm{cm}^{2}$ / s) are $1.98 \times 10^{-5}$ for $\mathrm{Cl}^{-}$(Lobo et al. 1998), $1.88 \times 10^{-5}$ for $\mathrm{CH}_{4}$ (Witherspoon and Saraf 1965), $1.90 \times 10^{-5}$ for $\mathrm{Ar}$ (Yaws 2010), and $2.20 \times 10^{-5}$ for $\mathrm{O}_{2}$ (Ferrell and Himmelblau 1967).

Absolute rates of $\mathrm{CH}_{4}$ oxidation $\left(\mu \mathrm{mol} 1^{-1} \mathrm{~h}^{-1}\right)$ were determined by multiplying $k$ estimates from individual data segments by the corresponding average $\mathrm{CH}_{4}$ concentration or by the minimum and maximum $\mathrm{CH}_{4}$ concentration observed in respective segments. In this fashion, a range of $\mathrm{CH}_{4}$ oxidation rates was obtained for each PPT. Note that for the calculation of rates derived by ${ }^{13} \mathrm{C}$ PPT, total $\mathrm{CH}_{4}$ concentration, i.e. the sum of ${ }^{13} \mathrm{C}-\mathrm{CH}_{4}$ and ${ }^{12} \mathrm{C}-\mathrm{CH}_{4}$ background concentration, was used.

\section{Results}

Root-zone $\mathrm{O}_{2}$ dynamics

Oxygen concentrations near the roots of all four rice plants showed a circadian pattern with increasing $\mathrm{O}_{2}$ concentrations at daytime and decreasing $\mathrm{O}_{2}$ concentrations to below detection at nighttime (Fig. 3). This pattern was similar for all plants; however, the magnitude of $\mathrm{O}_{2}$ concentrations differed between plants with peak $\mathrm{O}_{2}$ concentrations during daytime ranging between 90 and $250 \%$ air saturation. All plants showed a rapid change in $\mathrm{O}_{2}$ concentrations in response to light conditions, but with some delay with respect to the onset of dawn and dusk. This delay was most pronounced for the rice plant shown in Fig. 3b, where $\mathrm{O}_{2}$ concentrations near the roots began to increase only about $6 \mathrm{~h}$ after the onset of dawn. Small fluctuations at the beginning of measurements (Fig. 3c, d) may have arisen from the time needed to equilibrate the probe after emplacement.

Push-pull test performance

In all PPTs, BTCs for $\mathrm{Cl}^{-}$showed a continuous decline in $\mathrm{C}^{*}$, indicating that test solution was

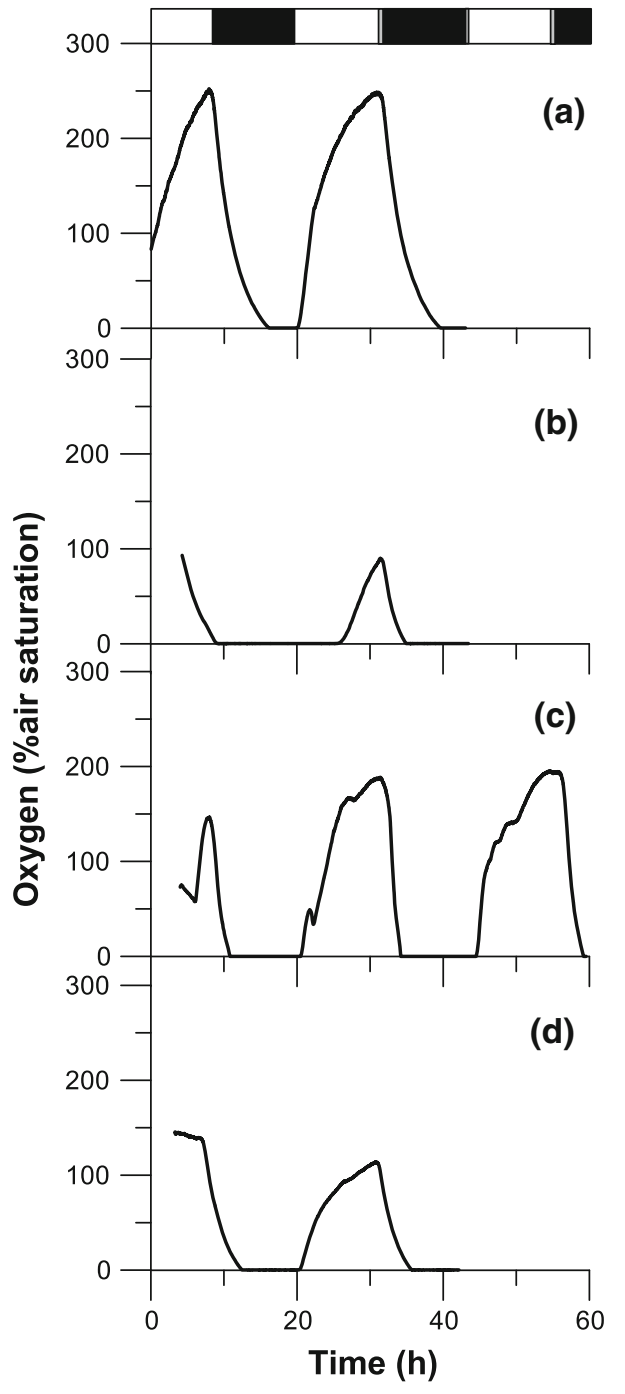

Fig. 3 Root $\mathrm{O}_{2}$ dynamics in four different rice plants (Oryza sativa). Night (black bar), day (open bar), transition zone (grey bar). Note that measurements in $a, b$ and $d$ were terminated at $\mathrm{t}$ $\cong 42 \mathrm{~h}$

increasingly diluted with background pore water during the PPTs' extraction phase (Fig. 4). Initially the decline was fast, but this was followed by a slower decline during later stages of extraction. Breakthrough curves for $\mathrm{Ar}$ and $\mathrm{CH}_{4}$ generally exhibited a similar pattern. However, in most cases relative $\mathrm{Cl}^{-}$concentrations were higher than relative $\mathrm{Ar}$ concentrations indicating that some Ar was lost from the system in addition to the dilution accounted for by $\mathrm{Cl}^{-}$. Towards the end of extraction, relative $\mathrm{Ar}$ and $\mathrm{Cl}^{-}$concentrations leveled off to a nearly constant value, which was used for background correction when the originally 
Fig. 4 Selected extraction breakthrough curves showing relative concentrations $\left(C^{*}\right)$ of $\mathrm{CH}_{4}$, $\mathrm{Cl}^{-}$and $\mathrm{Ar}$ for standard PPTs conducted at daytime (a, b), late nighttime (c, d) and early nighttime (e, f), and for daytime ${ }^{13} \mathrm{C}$-PPTs $(\mathbf{g}, \mathbf{h})$
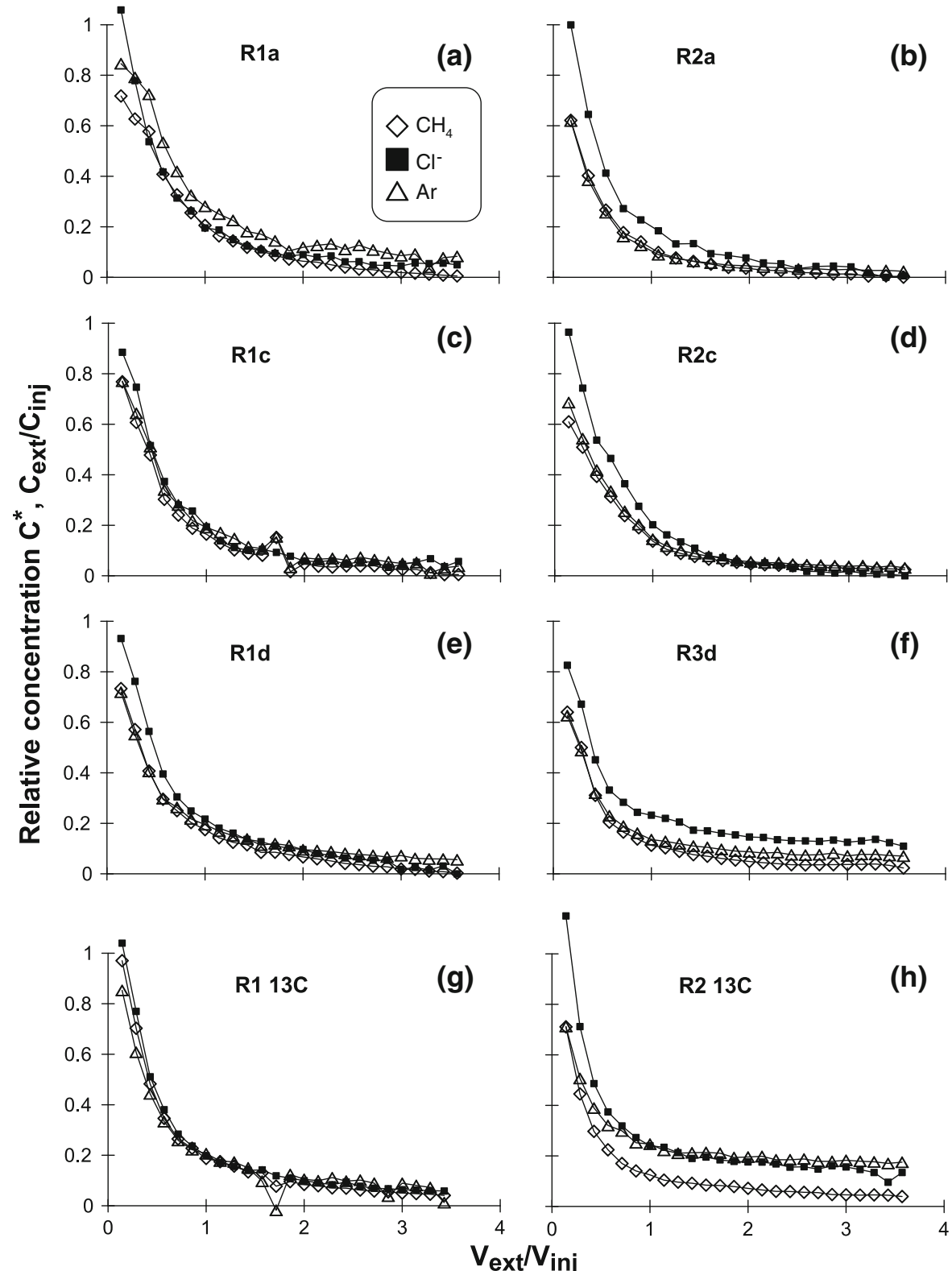

R2 13C

(h)

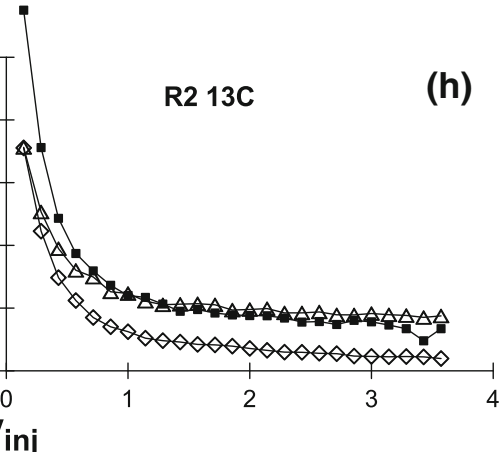

measured background value was higher than this value. Finally, relative $\mathrm{CH}_{4}$ concentrations were usually smaller than relative $\mathrm{Ar}$ concentrations, in particular during later stages of extraction (Fig. 4). This was considered to be indicative of $\mathrm{CH}_{4}$ consumption.

Mass recovery of $\mathrm{Cl}^{-}$, $\mathrm{Ar}$ and $\mathrm{CH}_{4}$ was computed from respective BTCs for those data segments that were subsequently employed for the calculation of rate constants. Early-time data points were omitted from these calculations (system dead volume), thus values of relative mass recovered (total mass recovered/total mass injected $\times 100 \%$ ) were always substantially smaller than $100 \%$ (Table 2). Relative mass recoveries of $\mathrm{Cl}^{-}(22-65 \%)$ were commonly higher than for Ar (13-60\%), while $\mathrm{CH}_{4}$ usually exhibited the smallest relative mass recoveries (5-30\%). A slightly higher mass recovery for $\mathrm{CH}_{4}$ compared to Ar was obtained in the inhibition test (R5 inhib., Table 2), whereas a substantially lower mass recovery for $\mathrm{CH}_{4}$ was obtained in $\mathrm{R} 5$ act., indicating $\mathrm{CH}_{4}$ consumption during the latter test. Note that for calculation of rate 
Table 2 Estimates of rate constants $k$ (with $95 \%$ confidence intervals $2 \sigma_{k}$ ) for two individual data segments of $20 \mathrm{PPTs}$, mean $^{\mathrm{C}} \mathrm{H}_{4}$ oxidation rates for data segments, and relative mass recovery of $\mathrm{Cl}^{-}, \mathrm{Ar}$ and $\mathrm{CH}_{4}$

\begin{tabular}{|c|c|c|c|c|c|c|c|c|}
\hline \multirow[t]{2}{*}{ PPT } & \multirow[t]{2}{*}{ Time } & \multicolumn{2}{|c|}{ Segment 1 (early-time) } & \multicolumn{2}{|c|}{ Segment 2 (late-time) } & \multicolumn{3}{|c|}{ Relative mass recovery } \\
\hline & & $\mathrm{k} \pm 2 \sigma_{\kappa}\left(\mathrm{h}^{-1}\right)$ & $\begin{array}{l}\text { Mean rate } \\
\left(\mu \mathrm{mol} 1^{-1} \mathrm{~h}^{-1}\right)\end{array}$ & $\mathrm{k} \pm 2 \sigma_{\kappa}\left(\mathrm{h}^{-1}\right)$ & $\begin{array}{l}\text { Mean rate } \\
\left(\mu \mathrm{mol} 1^{-1} \mathrm{~h}^{-1}\right)\end{array}$ & $\mathrm{Cl}^{-}(\%)$ & $\operatorname{Ar}(\%)$ & $\mathrm{CH}_{4}(\%)$ \\
\hline $\mathrm{R} 1 \mathrm{a}$ & $\mathrm{D}$ & $1.1 \pm 0.98$ & 84 & $7.9 \pm 1.26$ & 185 & 31 & 46 & 25 \\
\hline $\mathrm{R} 2 \mathrm{a}$ & $\mathrm{D}$ & $3.5 \pm 0.59$ & 99 & $13.5 \pm 8.63$ & 232 & 24 & 15 & 13 \\
\hline $\mathrm{R} 4 \mathrm{a}$ & $\mathrm{D}$ & $1.3 \pm 0.86$ & 67 & $7.0 \pm 2.47$ & 244 & 41 & 20 & 25 \\
\hline $\mathrm{R} 1 \mathrm{~b}$ & $\mathrm{D}$ & $1.9 \pm 0.41$ & 109 & $8.4 \pm 2.20$ & 315 & 32 & 25 & 19 \\
\hline $\mathrm{R} 2 \mathrm{~b}$ & $\mathrm{D}$ & $3.1 \pm 1.90$ & 96 & $21.6 \pm 4.58$ & 359 & 32 & 13 & 11 \\
\hline $\mathrm{R} 3 \mathrm{~b}$ & $\mathrm{D}$ & $2.3 \pm 0.15$ & 62 & $6.1 \pm 1.10$ & 96 & 43 & 24 & 14 \\
\hline $\mathrm{R} 4 \mathrm{~b}$ & $\mathrm{D}$ & $2.7 \pm 0.91$ & 129 & $15.1 \pm 6.37$ & 451 & 48 & 21 & 23 \\
\hline $\mathrm{R} 1 \mathrm{c}$ & $\mathrm{LN}$ & $2.0 \pm 0.83$ & 37 & n.a. ${ }^{\mathrm{a}}$ & n.a. ${ }^{\mathrm{a}}$ & 27 & 29 & 21 \\
\hline $\mathrm{R} 2 \mathrm{c}$ & $\mathrm{LN}$ & $0.7 \pm 0.15$ & 13 & n.a. ${ }^{a}$ & n.a. ${ }^{\mathrm{a}}$ & 23 & 22 & 19 \\
\hline $\mathrm{R} 4 \mathrm{c}$ & $\mathrm{LN}$ & $-0.5 \pm 0.19^{\mathrm{b}}$ & -11 & n.a. ${ }^{a}$ & n.a. ${ }^{a}$ & 26 & 26 & 26 \\
\hline R1d & $\mathrm{EN}$ & $2.2 \pm 0.49$ & 134 & $8.4 \pm 1.82$ & 82 & 30 & 33 & 23 \\
\hline $\mathrm{R} 2 \mathrm{~d}$ & EN & $4.0 \pm 0.21$ & 93 & n.a. ${ }^{a}$ & n.a. ${ }^{a}$ & 57 & 20 & 14 \\
\hline $\mathrm{R} 3 \mathrm{~d}$ & EN & $2.5 \pm 0.23$ & 81 & n.a. ${ }^{\mathrm{a}}$ & n.a. ${ }^{\mathrm{a}}$ & 48 & 29 & 18 \\
\hline $\mathrm{R} 4 \mathrm{~d}$ & $\mathrm{LN}$ & $0.5 \pm 0.11$ & 20 & n.a. ${ }^{a}$ & n.a. ${ }^{a}$ & 56 & 25 & 31 \\
\hline $\mathrm{R} 1{ }^{13} \mathrm{C}$ & $\mathrm{D}$ & $1.9 \pm 0.45$ & 95 & n.a. ${ }^{\mathrm{a}}$ & n.a. ${ }^{\mathrm{a}}$ & 34 & 30 & 30 \\
\hline $\mathrm{R} 2{ }^{13} \mathrm{C}$ & $\mathrm{D}$ & $2.2 \pm 0.19$ & 37 & n.a. ${ }^{a}$ & n.a. ${ }^{a}$ & 54 & 60 & 23 \\
\hline R3 ${ }^{13} \mathrm{C}$ & $\mathrm{D}$ & $0.8 \pm 0.52$ & 25 & n.a. ${ }^{a}$ & n.a. ${ }^{a}$ & 22 & 24 & 26 \\
\hline $\mathrm{R} 4{ }^{13} \mathrm{C}$ & $\mathrm{D}$ & $8.2 \pm 2.94$ & 292 & n.a. ${ }^{a}$ & n.a. ${ }^{\mathrm{a}}$ & 42 & 31 & 27 \\
\hline R5 act. & $\mathrm{D}$ & $3.7 \pm 0.98$ & 13 & $6.4 \pm 1.3$ & 11 & 65 & 15 & 05 \\
\hline R5 inhib. & D & $-0.3 \pm 0.41^{\mathrm{b}}$ & -2 & n.a. ${ }^{a}$ & n.a. ${ }^{a}$ & 42 & 28 & 34 \\
\hline
\end{tabular}

Early-time data (first 5 data points) were omitted from calculations, as they represented the system's dead volume

a n.a.: no regression line was fitted for segment 2, as data exhibited a single slope (i.e., one $k$ value)

b Production of methane is indicated with a (-) sign

constants high mass recovery is not a prerequisite (Haggerty et al. 1998).

\section{Standard PPTs to quantify $\mathrm{CH}_{4}$ oxidation}

Several data sets exhibited a curved rather than a linear decrease in $\ln \left(C_{\mathrm{CH}_{4}}^{*} / C_{\mathrm{Ar}}^{*}\right)$ during extraction, an example is shown in R4b data (Fig. 5). We chose to process curved PPT data sets in two quasi-linear segments, thus yielding two $k$ values (Table 2). In standard PPTs, smaller $k$ values ranging from $0.5-4 \mathrm{~h}^{-1}$ were obtained for early-time data when absolute $\mathrm{CH}_{4}$ concentrations were high, while $k$ values for late-time data (when $\mathrm{CH}_{4}$ concentrations were small) ranged from $6.1-21.6 \mathrm{~h}^{-1}$.

In general, calculated mean rates showed a high variability especially at daytime and early nighttime (Table 2). PPTs conducted at late nighttime resulted either in low rates of $\mathrm{CH}_{4}$ oxidation or even in slight production of $\mathrm{CH}_{4}$ (negative rates in Table 2; $\mathrm{R} 4 \mathrm{c}$ data set in Fig. 5). Adding $\mathrm{O}_{2}$ to the injection solution had little effect on rate constants and $\mathrm{CH}_{4}$ oxidation rates (Table 2). In those experiments, $\mathrm{O}_{2}$ concentration declined rapidly to below detection early during extraction (data not shown), indicating that $\mathrm{O}_{2}$ was rapidly consumed in the soil.

Verification of standard PPT procedure and microbial $\mathrm{CH}_{4}$ oxidation

Daytime PPTs with ${ }^{13} \mathrm{CH}_{4}$ were conducted to test if flushing before standard PPTs had any adverse effects on $\mathrm{CH}_{4}$ oxidation. Breakthrough curves similar to those of standard PPTs were obtained for ${ }^{13} \mathrm{C}$ PPTs (examples in Fig. $4 \mathrm{~g}$, h). Rate plots for all ${ }^{13} \mathrm{C}$ PPTs exhibited one quasi-linear segment (not shown), from 


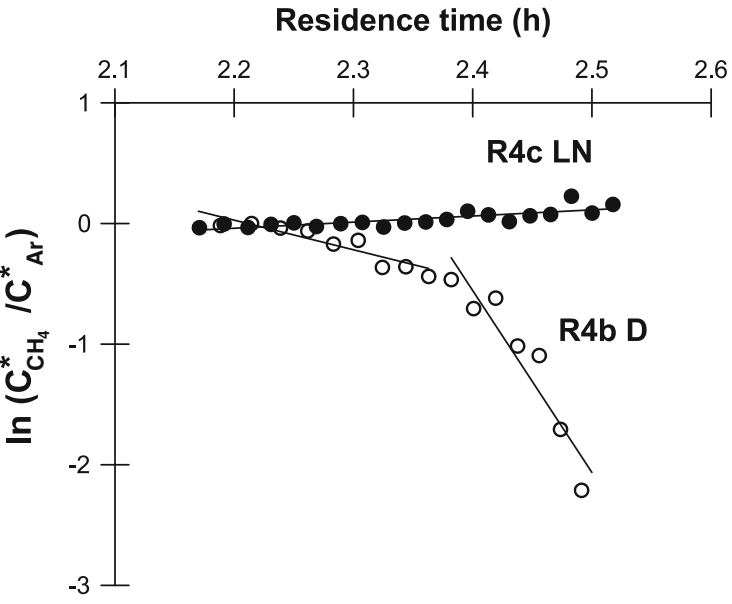

Fig. 5 Plot to determine rate constants $k$ for PPTs conducted during late nighttime (LN) and daytime (D) in rice pot R4

which a single rate constant was computed for each test (Table 2). The resulting $k$ values ranged between 0.8 and $8.2 \mathrm{~h}^{-1}$ (Table 2). Calculated rates were in the range of daytime standard PPTs ranging from 25 up to $292 \mu \mathrm{mol} \mathrm{l}^{-1} \mathrm{~h}^{-1}$ (Table 2), also exhibiting substantial variability.

The rate plot for PPT R5 act. (without $\mathrm{C}_{2} \mathrm{H}_{2}$, Fig. 6) exhibited a pattern similar to daytime standard PPTs, displaying two quasi-linear data segments. Consequently, calculated $k$ values (3.7 and $6.4 \mathrm{~h}^{-1}$, Table 2) were in the same range as for daytime PPTs. However, the computed $\mathrm{CH}_{4}$ oxidation rate $\left(13 \mu \mathrm{mol} \mathrm{l}^{-1} \mathrm{~h}^{-1}\right.$, Table 2) was substantially lower than rates of other

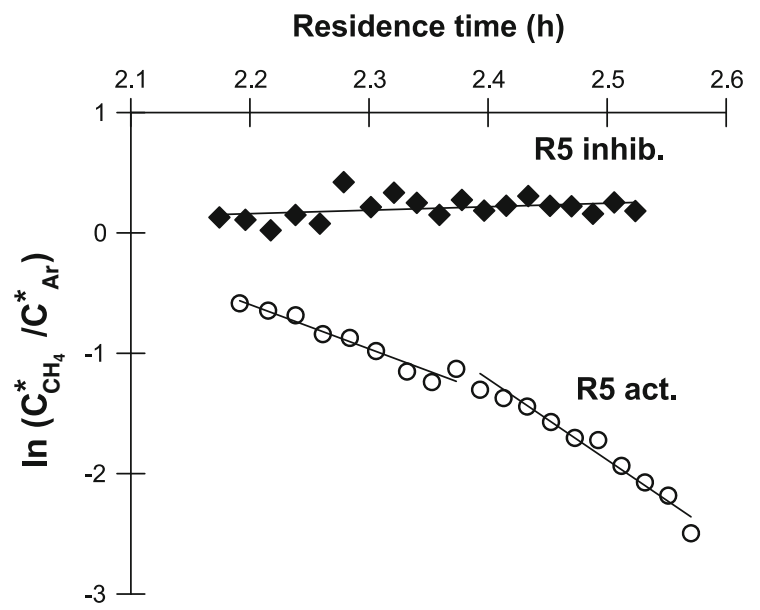

Fig. 6 Plot to determine rate constants $k$ for PPT R5 act. (without $\mathrm{C}_{2} \mathrm{H}_{2}$ ), and PPT R5 inhib. (with $\mathrm{C}_{2} \mathrm{H}_{2}$ to inhibit $\mathrm{CH}_{4}$ oxidation) daytime PPTs. This was due to the smaller $\mathrm{CH}_{4}$ injection concentration employed in PPT R5 act. (Table 1). Conversely, the rate plot for PPT R5 inhib. (with $\mathrm{C}_{2} \mathrm{H}_{2}$, Fig. 6) exhibited a flat, quasi-linear data segment. Note the similarity of these data with data obtained for late nighttime PPT R4c (Fig. 5).

\section{Discussion}

Root-zone $\mathrm{O}_{2}$ dynamics

Data presented here (Fig. 3) support previous findings in that $\mathrm{O}_{2}$ concentrations increased in the root zone during daytime and decreased at nighttime, thus following a circadian pattern (Frenzel et al. 1992; Waters et al. 1989). The increase of $\mathrm{O}_{2}$ concentration was indicative of $\mathrm{O}_{2}$ production coupled to diffusional transport through the plants' aerenchyma, whereas a decrease might be caused by root respiration, and/or chemical and microbial $\mathrm{O}_{2}$ consumption in rice soil. A noticeable delay in $\mathrm{O}_{2}$ concentration increase at dawn (Fig. 3b) was possibly due to root/shoot junction resistance (van der Gon and van Breemen 1993), which would have increased the time necessary for the buildup of a sufficiently large $\mathrm{O}_{2}$ concentration gradient. Moreover, the time required for $\mathrm{O}_{2}$ to diffuse from roots surfaces to the $\mathrm{O}_{2}$ probe might have created an additional delay. This delay, however, we would expect to be similar in magnitude for all $\mathrm{O}_{2}$ measurements.

Peak $\mathrm{O}_{2}$ concentrations in our study $(250 \%$ air saturation in Fig. $3 \mathrm{a}$ corresponds to $688 \mu \mathrm{M} \mathrm{O} \mathrm{O}_{2}$ dissolved in water) were highly variable and substantially higher compared to other studies measuring $\mathrm{O}_{2}$ availability in rice soil (10 to $150 \mu \mathrm{M} \mathrm{O}_{2}$ (Frenzel et al. 1992), and 0 to $96 \mu \mathrm{M}$ in dim light (Revsbech et al. 1999)). This might be caused by several factors, including a lower $\mathrm{O}_{2}$ demand in the vicinity of the roots, as roots were separated from bulk soil by the measuring cell. Bulk soil (reduced conditions) is usually a major sink for $\mathrm{O}_{2}$. In addition, we noted patchy red-brownish precipitates on root surfaces, which may be indicative of a heterogeneous $\mathrm{O}_{2}$ distribution. The precipitates were likely iron oxides, which are commonly found on rice roots (Chen et al. 1980; Macfie and Crowder 1987). Furthermore, $\mathrm{O}_{2}$ concentration in the root zone may also be influenced by plant-growth conditions (Colmer et al. 1998) and 
by the roots' physiological condition (Colmer 2003). Thus, having used roots of healthy appearance for our measurements (omitting decaying, blackish and fully encrusted roots) may explain in part the high $\mathrm{O}_{2}$ concentrations observed.

Nonetheless, both the distinct circadian pattern and the magnitude of $\mathrm{O}_{2}$ concentration were a clear indication that photosynthetic activity in the plant canopy was an important factor for $\mathrm{O}_{2}$ delivery to the root zone, as maximum $\mathrm{O}_{2}$ concentrations near the roots substantially exceeded atmospheric $\mathrm{O}_{2}$ saturation (Fig. 3).

\section{Circadian pattern of $\mathrm{CH}_{4}$ oxidation}

Methane oxidation rates obtained at daytime were considerably higher than at late nighttime (Fig. 7), which is in agreement with the measured circadian pattern of $\mathrm{O}_{2}$ concentration. During early nighttime, $\mathrm{O}_{2}$ was apparently still supplied to the root zone, as seen from the gradual decline in $\mathrm{O}_{2}$ concentration at the onset of nighttime (Fig. 3). Consequently, $\mathrm{CH}_{4}$ oxidation rates obtained at early nighttime were similar to daytime rates and thus substantially higher than at late nighttime (Fig. 7). At late nighttime, we

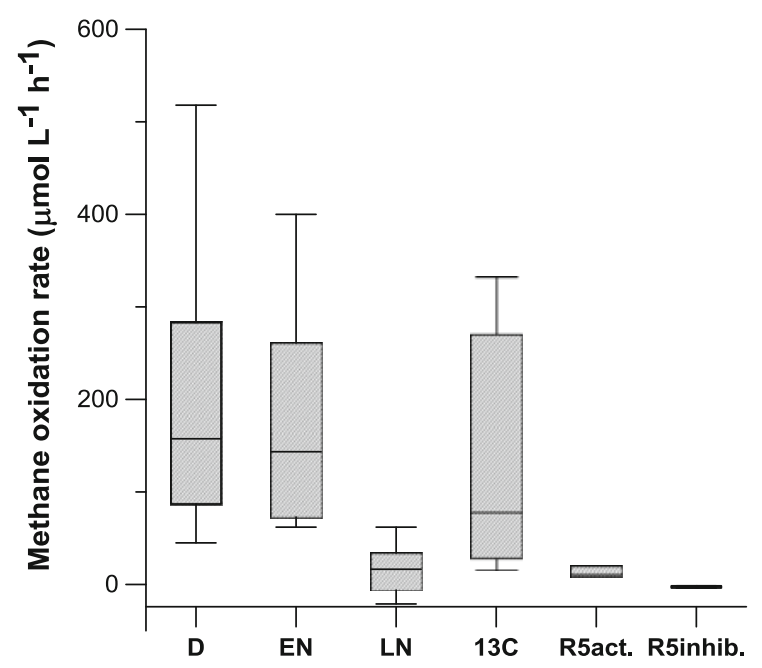

Fig. 7 Box-whisker plot for comparison of maximum and minimum $\mathrm{CH}_{4}$ oxidation rates obtained from PPTs conducted at daytime (D), early nighttime (EN), and late nighttime (LN), and for ${ }^{13} \mathrm{C}$ PPTs (daytime) and PPTs R5 act. (without $\mathrm{C}_{2} \mathrm{H}_{2}$ ) and R5 inhib. (with $\mathrm{C}_{2} \mathrm{H}_{2}$ ). Boxes reflect 25 and 75 percentiles, horizontal lines show median values, whiskers show maximum and minimum values. Note that PPT R5 inhib. yielded only a single data point detected either low $\mathrm{CH}_{4}$ oxidation rates or even slight production of $\mathrm{CH}_{4}$ (Fig. 7; Table 2). Possibly, $\mathrm{CH}_{4}$ was produced in regions of the rice soil where BES was not entirely efficient in inhibiting $\mathrm{CH}_{4}$ production. Nonetheless, our data suggest that $\mathrm{CH}_{4}$ oxidation at daytime was largely fuelled by photosynthetically produced $\mathrm{O}_{2}$. At late nighttime, low rates of $\mathrm{CH}_{4}$ oxidation clearly indicated an $\mathrm{O}_{2}$ limitation, as similar $\mathrm{CH}_{4}$ injection concentrations were employed in all standard PPTs (Table 1). Our results are in general agreement with several previous studies (e.g., Oremland and Taylor 1977), but they contrast results obtained by Van der Nat et al. (1998), who employed the $\mathrm{CH}_{3} \mathrm{~F}$ inhibition flux chamber technique and found little effect of light conditions on $\mathrm{CH}_{4}$ oxidation in the root zone of wetland plants Phragmites australis and Scirpus lacrustris.

To allow a comparison of $\mathrm{CH}_{4}$ oxidation rates obtained in this study with literature values, we converted our data to units of $\mu \mathrm{mol} g$ (dry weight, d.w. $)^{-1} \mathrm{~h}^{-1}$ using an estimated porosity of 0.52 (loamy sand) and assuming water-saturated conditions. Rates calculated for standard PPTs' segment 1 (Table 2) ranged from 0.01 to $0.56 \mu \mathrm{mol} g(\mathrm{~d} . w .)^{-1}$ $\mathrm{h}^{-1}$. They were in the range of data reported for shortterm soil-slurry incubations of rhizospheric rice soil (0.01-0.2 $\mu \mathrm{mol} \mathrm{g}$ (d.w.) $)^{-1} \mathrm{~h}^{-1}$ (Henckel et al. 2000)), but were lower than rates obtained after long-term incubation (up to $2 \mu \mathrm{mol} \mathrm{g}$ (d.w.) ${ }^{-1} \mathrm{~h}^{-1}$ (Bosse and Frenzel 1997; Eller and Frenzel 2001), and higher in comparison to bulk soil incubations $(<0.01 \mu \mathrm{mol}$ $\mathrm{g}^{-1} \mathrm{~h}^{-1}$, no indication if dry or wet weight (Wang et al. 1997)). Conversely, higher rates (up to $9 \mu \mathrm{mol}$ $\mathrm{g}(\text { d.w. })^{-1} \mathrm{~h}^{-1}$ ) were calculated for standard PPTs' segment 2 (Table 2), which may have been the result of increased $\mathrm{O}_{2}$ availability and longer reaction/contact time of that portion of test solution in the root zone (due to longer travel distance (Haggerty et al. 1998)). In general, high variability of calculated in situ $\mathrm{CH}_{4}$ oxidation rates was considered an indication for the system's heterogeneity.

Verification of standard PPT procedure and microbial $\mathrm{CH}_{4}$ oxidation

Our study revealed only slight differences in rate constants and rates of $\mathrm{CH}_{4}$ oxidation between daytime standard and ${ }^{13} \mathrm{C}$-PPTs (Table 2; Fig. 7). Hence, ${ }^{13} \mathrm{C}$ PPTs indicated that extensive flushing prior to 
injection of test solution during standard PPTs had little adverse effects on measured $\mathrm{CH}_{4}$ oxidation rates. Indeed, a slightly higher variability in rate constants and $\mathrm{CH}_{4}$ oxidation rates in ${ }^{13} \mathrm{C}$-PPTs compared to daytime standard PPTs was noticeable (Table 2), which might indicate that flushing reduced adverse effects of variable background concentrations in standard PPTs. While ${ }^{13} \mathrm{C}$-PPTs allowed performing tests with less disturbance (less flushing) to the system, standard PPTs required less complex analytical methods (no mass spectrometry required); the latter are therefore more cost effective for routine applications.

Finally, we verified that $\mathrm{CH}_{4}$ oxidation was microbially mediated by conducting an active test followed by an inhibition test. Results clearly showed that $\mathrm{CH}_{4}$ was consumed during PPT R5 act., whereas $\mathrm{CH}_{4}$ oxidation was effectively inhibited by $\mathrm{C}_{2} \mathrm{H}_{2}$ during PPT R5 inhib (Figs. 6, 7). Similar to late nighttime PPTs, a slight production of $\mathrm{CH}_{4}$ during the active test may indicate that BES was not entirely efficient in inhibiting $\mathrm{CH}_{4}$ production. However, as a result of BES added to the PPTs' test solutions $\mathrm{CH}_{4}$ production was low in magnitude compared to $\mathrm{CH}_{4}$ oxidation, e.g., in daytime PPTs. Consequently, any underestimation of $\mathrm{CH}_{4}$ oxidation rates as a result of concurrent $\mathrm{CH}_{4}$ production was expected to be small.

\section{Conclusions}

We successfully adapted the PPT method to quantify $\mathrm{CH}_{4}$ oxidation in situ in the root zone of rice plants. In these PPTs, we employed both ionic and dissolved-gas tracers to account for dilution with background pore water as well as dissolved-gas transport phenomena. Our results indicated that $\mathrm{CH}_{4}$ oxidation followed a circadian pattern. This suggests that $\mathrm{CH}_{4}$ oxidation was mainly limited by $\mathrm{O}_{2}$ availability in the rice-root zone, which was supported by our $\mathrm{O}_{2}$ concentration measurements. Extensive flushing prior to standard PPTs to reduce $\mathrm{CH}_{4}$ background concentrations in pore water appeared to have little adverse effect on measured $\mathrm{CH}_{4}$ oxidation rates, as was confirmed in separate PPTs employing ${ }^{13} \mathrm{CH}_{4}$. With further adaptation, the presented methodology may be used to quantify a variety of processes in situ in the root zone of plants in waterlogged habitats, e.g. wetlands.
Acknowledgments We thank Christof Sautter and his team for the cultivation of the rice plants, and Ruben Kretzschmar (all at ETH Zurich) for providing the climate chamber. Funding for this project was provided by ETH Zurich through grant no. TH$2006-3$.

\section{References}

Armstrong W (1964) Oxygen diffusion from the roots of some british bog plants. Nature 204(4960):801-802

Bassein E, Jaffe PR (2009) Measuring in situ reaction rate constants in wetland sediments. Environ Monit and Assess 159(1-4):51-62

Bosse U, Frenzel P (1997) Activity and distribution of methaneoxidizing bacteria in flooded rice soil microcosms and in rice plants (oryza sativa). Appl Environ Microbiol 63(4):1199-1207

Butterbach-Bahl K, Papen H, Rennenberg H (1997) Impact of gas transport through rice cultivars on methane emission from rice paddy fields. Plant Cell Environ 20(9):11751183

Calhoun A, King GM (1997) Regulation of root-associated methanotrophy by oxygen availability in the rhizosphere of two aquatic macrophytes. Appl Environ Microbiol 63(8): 3051-3058

Chanton JP, Whiting GJ, Blair NE, Lindau CW, Bollich PK (1997) Methane emission from rice: Stable isotopes, diurnal variations, and $\mathrm{CO}_{2}$ exchange. Global Biogeochem Cycles 11(1):15-27

Chen CC, Dixon JB, Turner FT (1980) Iron coatings on rice roots-mineralogy and quantity influencing factors. Soil Sci Soc Am J 44(3):635-639

Christensen PB, Revsbech NP, Sand-Jensen K (1994) Microsensor analysis of oxygen in the rhizosphere of the aquatic macrophyte Littorella uniflora (L.) ascherson. Plant Physiol 105(3):847-852

Colmer TD (2003) Long-distance transport of gases in plants: a perspective on internal aeration and radial oxygen loss from roots. Plant Cell Environ 26(1):17-36

Colmer TD, Pedersen O (2008) Oxygen dynamics in submerged rice (Oryza sativa). New Phytol 178(2):326-334

Colmer TD, Gibberd MR, Wiengweera A, Tinh TK (1998) The barrier to radial oxygen loss from roots of rice (Oryza sativa L.) is induced by growth in stagnant solution. J Exp Bot 49(325):1431-1436

Conrad R, Rothfuss F (1991) Methane oxidation in the soil surface layer of a flooded rice field and the effect of ammonium. Biol Fertil Soils 12(1):28-32

Denman KL, Brasseur G, Chidthaisong A, Ciais P, Cox PM, Dickinson RE, Hauglustaine D, Heinze C, Holland E, Jacob D, Lohmann U, Ramachandran S, da Silva Dias PL, Wofsy SC, Zhang X (2007) Couplings between changes in the climate system and biogeochemistry. In: Solomon S, D. Qin, M. Manning, Z. Chen, M. Marquis, K.B. Averyt, M.Tignor and H.L. Miller (eds) Climate change 2007: The physical science basis. Contribution of working group I to the fourth assessment report of the Intergovernmental Panel on Climate Change 
Eller G, Frenzel P (2001) Changes in activity and community structure of methane-oxidizing bacteria over the growth period of rice. Appl Environ Microbiol 67(6):2395-2403

Eller G, Kruger M, Frenzel P (2005) Comparing field and microcosm experiments: a case study on methano- and methylo-trophic bacteria in paddy soil. FEMS Microbiol Ecol 51(2):279-291

Epp MA, Chanton JP (1993) Rhizospheric methane oxidation determined via the methyl fluoride inhibition technique. J Geophys Res Atm 98(D10):18413-18422

Ferrell RT, Himmelblau DM (1967) Diffusion coefficients of nitrogen and oxygen in water. J Chem Eng Data 12(1): 111-115

Forster P, Ramaswamy V, Artaxo P, Berntsen T, Betts R, Fahey DW, Haywood J, Lean J, Lowe DC, Myhre G, Nganga J, Prinn R, Raga G, Schulz M, Van Dorland R (2007) Changes in atmospheric constituents and in radiative forcing. In: Solomon S, Qin D, Manning M, Chen Z, Marquis M, Averyt KB, Tignor M, Miller HL (edS) Climate change 2007: the physical science basis. Contribution of working group I to the fourth assessment report of the Intergovernmental Panel on Climate Change

Frenzel P, Rothfuss F, Conrad R (1992) Oxygen profiles and methane turnover in a flooded rice microcosm. Biol Fertil Soils 14(2):84-89

Fuller EN, Schettle Pd, Giddings JC (1966) A new method for prediction of binary gas-phase diffusion coefficients. Ind Eng Chem 58(5):19-27

Gerard G, Chanton J (1993) Quantification of methane oxidation in the rhizosphere of emergent aquatic macrophytesdefining upper limits. Biogeochemistry 23(2):79-97

Gilbert B, Frenzel P (1995) Methanotrophic bacteria in the rhizosphere of rice microcosms and their effect on porewater methane concentration and methane emission. Biol Fertil Soils 20(2):93-100

Gilbert B, Frenzel P (1998) Rice roots and $\mathrm{CH}_{4}$ oxidation: the activity of bacteria, their distribution and the microenvironment. Soil Biol Biochem 30(14):1903-1916

Gomez KE, Gonzalez-Gil G, Lazzaro A, Schroth MH (2009) Quantifying methane oxidation in a landfill-cover soil by gas push-pull tests. Waste Manag 29(9):2518-2526

Gonzalez-Gil G, Schroth MH, Zeyer J (2007) Transport of methane and noble gases during gas push-pull tests in dry porous media. Environ Sci Technol 41(9):3262-3268

Groot TT, van Bodegom PM, Harren FJM, Meijer HAJ (2003) Quantification of methane oxidation in the rice rhizosphere using ${ }^{13} \mathrm{c}$-labelled methane. Biogeochemistry 64(3):355372

Hageman KJ, Field JA, Istok JD, Semprini L (2004) Quantifying the effects of fumarate on in situ reductive dechlorination rates. J Contam Hydrol 75(3-4):281-296

Haggerty R, Schroth MH, Istok JD (1998) Simplified method of "push-pull" test data analysis for determining in situ reaction rate coefficients. Ground Water 36(2):314-324

Hanson RS, Hanson TE (1996) Methanotrophic bacteria. Microbiol Rev 60(2):439-471

Henckel T, Roslev P, Conrad R (2000) Effects of $\mathrm{O}_{2}$ and $\mathrm{CH}_{4}$ on presence and activity of the indigenous methanotrophic community in rice field soil. Environ Microbiol 2(6): 666-679
Holzapfel-Pschorn A, Seiler W (1986) Methane emission during a cultivation period from an Italian rice paddy. J Geophys Res 91(D11):11803-11814

Holzapfel-Pschorn A, Conrad R, Seiler W (1985) Production, oxidation and emission of methane in rice paddies. FEMS Microbiol Lett 31(6):343-351

Istok JD, Humphrey MD, Schroth MH, Hyman MR, Oreilly KT (1997) Single-well, "push-pull" " test for in situ determination of microbial activities. Ground Water 35(4): 619-631

Kampbell DH, Vandegrift SA (1998) Analysis of dissolved methane, ethane, and ethylene in ground water by a standard gas chromatographic technique. J Chromatogr Sci 36(5):253-256

Kim Y, Istok JD, Semprini L (2006) Push-pull tests evaluating in situ aerobic cometabolism of ethylene, propylene, and cis1,2-dichloroethylene. J Contam Hydrol 82(1-2):165-181

King G (1996) In situ analyses of methane oxidation associated with the roots and rhizomes of a bur reed, Sparganium eurycarpum, in a maine wetland. Appl Environ Microbiol 62(12):4548-4555

Kleikemper J, Schroth MH, Sigler WV, Schmucki M, Bernasconi SM, Zeyer J (2002) Activity and diversity of sulfatereducing bacteria in a petroleum hydrocarbon-contaminated aquifer. Appl Environ Microbiol 68(4):1516-1523

Koop-Jakobsen K, Giblin AE (2009) New approach for measuring denitrification in the rhizosphere of vegetated marsh sediments. Limnol Oceanogr Methods 7:626-637

Krüger M, Frenzel P, Conrad R (2001) Microbial processes influencing methane emission from rice fields. Glob Change Biol 7(1):49-63

Krüger M, Eller G, Conrad R, Frenzel P (2002) Seasonal variation in pathways of $\mathrm{CH}_{4}$ production and in $\mathrm{CH}_{4}$ oxidation in rice fields determined by stable carbon isotopes and specific inhibitors. Glob Change Biol 8(3):265-280

Kumaraswamy S, Rath AK, Ramakrishnan B, Sethunathan N (2000) Wetland rice soils as sources and sinks of methane: a review and prospects for research. Biol Fertil Soils 31(6):449-461

Liesack W, Schnell S, Revsbech NP (2000) Microbiology of flooded rice paddies. FEMS Microbiol Rev 24(5):625-645

Lobo VMM, Ribeiro ACF, Verissimo LMP (1998) Diffusion coefficients in aqueous solutions of potassium chloride at high and low concentrations. J Mol Liq 78(1-2):139-149

Macfie SM, Crowder AA (1987) Soil factors influencing ferric hydroxide plaque-formation on roots of Typha latifolia L. Plant Soil 102(2):177-184

Massman WJ (1998) A review of the molecular diffusivities of $\mathrm{H}_{2} \mathrm{O}, \mathrm{CO}_{2}, \mathrm{CH}_{4}, \mathrm{Co}, \mathrm{O}^{-3}, \mathrm{SO}_{2}, \mathrm{NH}_{3}, \mathrm{~N}_{2} \mathrm{O}, \mathrm{NO}$, and $\mathrm{NO}_{2}$ in air, $\mathrm{O}^{-2}$ and $\mathrm{N}^{-2}$ near STP. Atmos Environ 32(6): 1111-1127

Nauer PA, Schroth MH (2010) In situ quantification of atmospheric methane oxidation in near-surface soils. Vadose Zone J 9(4):1052-1062

Nouchi I, Mariko S, Aoki K (1990) Mechanism of methane transport from the rhizosphere to the atmosphere through rice plants. Plant Physiol 94(1):59-66

Oremland RS, Taylor BF (1977) Diurnal fluctuations of $\mathrm{O}_{2}, \mathrm{~N}_{2}$, and $\mathrm{CH}_{4}$ in rhizosphere of Thalassia testudinum. Limnol Oceanogr 22(3):566-570 
Rao DK, Bhattacharya SK, Jani RA (2008) Seasonal variations of carbon isotopic composition of methane from Indian paddy fields. Glob Biogeochem Cycles 22(1):GB1004

Revsbech NP, Pedersen O, Reichardt W, Briones A (1999) Microsensor analysis of oxygen and $\mathrm{pH}$ in the rice rhizosphere under field and laboratory conditions. Biol Fertil Soils 29(4):379-385

Sander R (1999) Compilation of Henry's law constants for inorganic and organic species of potential importance in environmental chemistry (version 3) http://www.Henryslaw.org

Sanders IA, Trimmer M (2006) In situ application of the ${ }^{15} \mathrm{NO}_{3}$ isotope pairing technique to measure denitrification in sediments at the surface water-groundwater interface. Limnol Oceanogr Methods 4:142-152

Schroth MH, Istok JD (2006) Models to determine first-order rate coefficients from single-well push-pull tests. Ground Water 44(2):275-283

Schütz H, Seiler W, Conrad R (1989) Processes involved in formation and emission of methane in rice paddies. Biogeochemistry 7(1):33-53

Seiler W, Holzapfel-Pschorn A, Conrad R, Scharffe D (1983) Methane emission from rice paddies. J Atmos Chem 1(3):241-268

Urmann K, Gonzalez-Gil G, Schroth MH, Hofer M, Zeyer J (2005) New field method: gas push-pull tests for the in situ quantification of microbial activities in the vadose zone. Environ Sci Technol 39(1):304-310

van Bodegom P, Stams F, Mollema L, Boeke S, Leffelaar P (2001) Methane oxidation and the competition for oxygen in the rice rhizosphere. Appl Environ Microbiol 67(8): 3586-3597

van der Gon HACD, Neue H-U (1996) Oxidation of methane in the rhizosphere of rice plants. Biol Fertil Soils 22(4): 359-366 van der Gon HACD, van Breemen N (1993) Diffusion-controlled transport of methane from soil to atmosphere as mediated by rice plants. Biogeochemistry 21(3):177-190

van der Nat F-FWA, Middelburg JJ, Van Meteren D, Wielemakers A (1998) Diel methane emission patterns from Scirpus lacustris and Phragmites australis. Biogeochemistry 41(1):1-22

Wang ZP, Zeng D, Patrick WH (1997) Characteristics of methane oxidation in a flooded rice soil profile. Nutr Cycl Agroecosyst 49(1):97-103

Wassmann R, Papen H, Rennenberg H (1993) Methane emission from rice paddies and possible mitigation strategies. Chemosphere 26(1-4):201-217

Waters I, Armstrong W, Thompson CJ, Setter TL, Adkins S, Gibbs J, Greenway H (1989) Diurnal changes in radial oxygen loss and ethanol-metabolism in roots of submerged and non-submerged rice seedlings. New Phytol 113(4): 439-451

Witherspoon P, Saraf DN (1965) Diffusion of methane, ethane, propane and n-butane in water from 25 to 43 degrees. J Phys Chem 69(11):3752-3755

Yagi K, Tsuruta H, Minami K (1997) Possible options for mitigating methane emission from rice cultivation. Nutr $\mathrm{Cycl}$ Agroecosyst 49(1):213-220

Yaws CL (2010) Yaws' transport properties of chemicals and hydrocarbons (electronic edition). Knovel, Norwich. http:// knovel.com/web/portal/browse/display?_EXT_KNOVEL_ DISPLAY_bookid=2905\&VerticalID $=0$

Yoshinari T, Knowles R (1976) Acetylene inhibition of nitrous oxide reduction by denitrifying bacteria. Biochem Biophys Res Commun 69(3):705-710 